\title{
Nutrient Fluxes from Sediments in the San Francisco Bay Delta
}

\author{
Jeffrey C. Cornwell • Patricia M. Glibert • \\ Michael S. Owens
}

Received: 19 December 2012 /Revised: 25 October 2013 / Accepted: 3 December 2013 / Published online: 1 January 2014

(C) The Author(s) 2014. This article is published with open access at Springerlink.com

\begin{abstract}
In September 2011 and March 2012, benthic nutrient fluxes were measured in the San Francisco Bay Delta, across a gradient from above the confluence of the Sacramento and San Joaquin Rivers to Suisun Bay. Dark and illuminated core incubation techniques were used to measure rates of denitrification, nutrient fluxes (phosphate, ammonium, nitrate), and oxygen fluxes. While benthic nutrient fluxes have been assessed at several sites in northern San Francisco Bay, such data across a Delta-Bay transect have not previously been determined. Average September rates of DIN (nitrate, nitrite, ammonium) flux were net positive across all sites, while March DIN flux indicated net uptake of DIN at some sites. Denitrification rates based on the $\mathrm{N}_{2} / \mathrm{Ar}$ ratio approach were between 0.6 and $1.0 \mathrm{mmol} \mathrm{m}^{-2} \mathrm{day}^{-1}$, similar to other mesotrophic estuarine sediments. Coupled nitrification-denitrification was the dominant denitrification pathway in September, with higher overlying water nitrate concentrations in March resulting in denitrification driven by nitrate flux into the sediments. Estimated benthic microalgal productivity was variable and surprisingly high in Delta sediments and may represent a major source of labile carbon to this ecosystem. Variable N/P stoichiometry was observed in these sediments, with deviations from Redfield driven by processes such as denitrification, variable light/dark uptake of nutrients by microalgae, and adsorption of soluble reactive phosphorus.
\end{abstract}

Keywords Benthic flux $\cdot$ Denitrification $\cdot$ Nutrient stoichiometry $\cdot \mathrm{N} / \mathrm{P}$ ratios $\cdot \mathrm{P}$ efflux $\cdot$ Benthic microalgae

Communicated by Craig Tobias

J. C. Cornwell $(\bowtie) \cdot$ P. M. Glibert • M. S. Owens

Horn Point Laboratory, University of Maryland Center for

Environmental Science, PO Box 775, Cambridge, MD 21613, USA

e-mail: cornwell@umces.edu

\section{Introduction}

Management issues related to the San Francisco Bay Delta are complex. Many management questions and actions are directly affected by the extent to which the factors contributing to food web changes can be identified and managed. Several fish, including the delta smelt (Hypomesus transpacificus) and longfin smelt (Spirinchus thaleichthys), are on the federal endangered species list or are considered threatened (Wanger 2007a, b). Water exports have been restricted by court order in recent years in an attempt to restore these species; new habitat is being created with the hope that it will contribute positively to the restoration of the system; and proposed major re-engineering of the flow is also being debated (e.g., Bay Delta Conservation Plan, 2010, http:// baydeltaconservationplan.com/BDCPPlanningProcess/ ReadDraftPlan/ReadDraftPlan_copy1.aspx).

Nutrient cycling bears on these issues in multiple ways. The estuary has been considered to have chronically low rates of productivity (e.g., Jassby et al. 2002; Kimmerer et al. 2012). Nutrient loads, speciation, and stoichiometry affect productivity and phytoplankton composition and ultimately can alter trophodynamics (e.g., Berg et al. 2001; Kemp et al. 2005; Glibert 2010, 2012; Glibert et al. 2011; Parker et al. 2012). While impacts of nutrients have long been ignored in this system compared to other stressors such as invasive bivalves (Alpine and Cloern 1992; Greene et al. 2011), nutrients are now gaining attention as important ecosystem stressors (Dugdale et al. 2007; van Nieuwenhuyse 2007; Jassby 2008; Glibert 2010, 2012; Glibert et al. 2011; Parker et al. 2012). Nutrients loads have increased substantially over the past decades due to increased sewage effluent loads (Van Nieuwenhuyse 2007; Dugdale et al. 2007; Glibert et al. 2011). Yet, despite the increasing recognition of nutrients as a potential stressor for this system, an accurate accounting of nutrient sources and sinks in the Bay Delta is not available. Without consideration of the role of nutrient sources and fluxes, the 
potential success of restoration of habitat restoration for native species will likely remain unpredictable.

Sediments are key components of shallow water estuarine ecosystems, both responding to changing environmental conditions and, at the same time, modifying the chemistry of the overlying water column. The role of sediments as "sinks" of contaminants, organic matter, and nutrients has been studied for decades, and their role as nutrient transformers has been well described. Sediments can be sinks for nutrients via burial and microbial denitrification and via assimilation into benthic algae and rooted macrophytes (Joye and Anderson 2008; Lehtoranta et al. 2009). Conversely, sediments are also sources of remineralized nutrients to support water column primary production. Sediments recycle fixed nitrogen $(\mathrm{N})$ and phosphorus (P) to the water column at rates that do not necessarily reflect their rates of deposition. Remineralized $\mathrm{N}$ can be returned to the water column as fixed $\mathrm{N}\left(\mathrm{NH}_{4}{ }^{+}\right.$or $\left.\mathrm{NO}_{x}\right)$ or as $\mathrm{N}_{2}$ after the process of denitrification. Phosphorus can be returned to the water column as soluble reactive $\mathrm{P}$ (SRP, essentially equivalent to $\mathrm{PO}_{4}{ }^{3-}$ ) or retained within the sediments as both inorganic (mineral or adsorbed) and organic P. Rates of sediment-water exchange of nutrients can be affected by a large number of factors, including input rates of labile $\mathrm{C}$, $\mathrm{N}$, and $\mathrm{P}$; presence/absence of dissolved $\mathrm{O}_{2}$ in overlying water (Mortimer 1971; Rysgaard et al. 1994; Kemp et al. 2005); salinity (Caraco et al. 1990; Gardner et al. 1991); availability of terminal electron acceptors including $\mathrm{NO}_{3}{ }^{-}, \mathrm{Mn}(\mathrm{IV})$, $\mathrm{Fe}(\mathrm{III})$, and $\mathrm{SO}_{4}{ }^{2-}$ (Anderson 1982; Cornwell et al. 1999; Lehtoranta et al. 2009); activity of bioturbating and bioirrigating animals (Aller 1980; Pelegri et al. 1994; Owens 2009); and pH (Seitzinger 1991; Glibert et al. 2011; Gao et al. 2012). The relative importance of sediment processes to the biogeochemistry of coastal systems is inversely related to the depth of the water column and directly related to the residence time of the water within the system (Nixon et al. 1996).

In systems in which $\mathrm{P}$ loading has been reduced from point source effluent or detergents, as occurred in the 1990s in the Bay Delta (Van Nieuwenhuyse 2007; Glibert 2010; Glibert et al. 2011), sediments can become the major source of this important macronutrient. In non-calcareous freshwater sediments, $\mathrm{P}$ is most often bound to iron oxyhydroxides $(\mathrm{FeOOH}$; Williams et al. 1971; Jordan et al. 2008). The FeOOH-bound P may be delivered to estuaries with transport of suspended solids or may become adsorbed to particulates when $\mathrm{P}$ is discharged from other sources, such as from point source discharges. When this bound $\mathrm{P}$ meets saline or sulfate-rich water, either from transport downestuary or from salt intrusion to sediments, formation of iron sulfide minerals can release $\mathrm{P}$ to overlying water (Caraco et al. 1990; Jordan et al. 2008; Lehtoranta et al. 2009). In the Bay Delta strong salinity gradients, shallow water depths and variable amounts of primary production/algal biomass are expected to have an important effect on sediment nutrient recycling (as in other coastal ecosystems; Boynton and Kemp 2008). Prior to this study, few measurements of sediment nutrient dynamics in the Bay Delta have been made (Caffrey 1995; Kuwabara et al. 2009).

Here, we report on a series of measurements of $\mathrm{N}\left(\mathrm{NH}_{4}{ }^{+}\right.$, $\mathrm{NO}_{3}{ }^{-}, \mathrm{N}_{2}-\mathrm{N}$ ) and $\mathrm{P}$ (soluble reactive $\mathrm{P}$ or SRP) fluxes from sites encompassing the salinity gradient in the Bay Delta region (e.g., Jassby et al. 1995). Our observations were conducted under high flow conditions in fall 2011 and in spring 2012. We hypothesized that fluxes of $\mathrm{N}$ from the sediment to the water column would be higher in late summer than in spring, that site differences would vary with $\mathrm{N}$ form, and that N/P stoichiometry of the fluxes would differ from Suisun Bay to upper Delta sites. We also hypothesized that shallow sediments in this system would be sites of considerable benthic productivity.

\section{Methodology}

Sampling and Experimentation

Sampling included a transect of 12 sites during each of two seasons, from the flooded islands above the confluence of the Sacramento and San Joaquin Rivers in the Bay Delta to Suisun Bay (Table 1, Fig. 1). Sediments were collected in "Delta" environments (including Mildred's Island, Franks Tract, Big Break, and Sherman Island) on September 14, 2011 and March 15, 2012, and in "Bay" environments (including Browns, Honker, Grizzly, and Suisun Bays) on September 16, 2011 and March 17, 2012. Each site was sampled in duplicate, except for Big Break in 2012, when six cores were collected from that site. An aluminum pole corer was used for sediment collection in the generally shallow deltaic environments, using $7 \mathrm{~cm}$ id acrylic cores with a sediment depth of $15 \mathrm{~cm}$. In the Bay environments, both the pole corer and a Soutar-designed non-metallic box corer were used. Sub-cores were inserted into the box corer at each site. Although undisturbed cores were collected at all sites, both sampling approaches had limitations: (1) the pole corer was able to collect samples to a water column depth of $\sim 3 \mathrm{~m}$, making core collection at Mildred's Island limited to a shallower water site on the northern edge, and (2) the box corer did not have sufficient penetration power at some deeper water sites, limiting sampling to shallow water sites.

At each site, the station location was recorded using GPS; photosynthetically active radiation (PAR) from both the water surface and the sediment surface was recorded using a $2 \pi$ LiCor light sensor, and salinity and temperature were measured using either YSI sondes or a Sea Bird CTD (selected bay sites only). At each site water was collected using rosettemounted water sampling bottles or by direct submersion of carboys at the shallow water sites for use in subsequent incubations as described below. 
Table 1 Site locations, salinity, temperature, and depth for sampling transect

\begin{tabular}{|c|c|c|c|c|c|c|c|}
\hline \multirow[t]{2}{*}{ Site } & \multirow{2}{*}{$\begin{array}{l}\text { Latitude } \\
\mathrm{N}\end{array}$} & \multirow{2}{*}{$\begin{array}{l}\text { Longitude } \\
\text { W }\end{array}$} & \multicolumn{2}{|l|}{ Salinity } & \multicolumn{2}{|l|}{ Temperature } & \multirow{2}{*}{$\begin{array}{l}\text { Depth } \\
\mathrm{m}\end{array}$} \\
\hline & & & September 11 & March 12 & $\begin{array}{l}\text { September } 11 \\
{ }^{\circ} \mathbf{C}\end{array}$ & March 12 & \\
\hline Mildred Island & 37.9975 & 121.5229 & 0.1 & 0.2 & 22.2 & 13.3 & 2.5 \\
\hline Franks Tract I & 38.0557 & 121.5886 & 0.1 & 0.2 & 21.6 & 12.8 & 1.1 \\
\hline Franks Tract II & 38.0262 & 121.6085 & 0.1 & 0.2 & 22.2 & 12.8 & 3.1 \\
\hline Big Break & 38.0221 & 121.7201 & 0.1 & 0.2 & 21.5 & 13.1 & 2.0 \\
\hline Sherman Island I & 38.0470 & 121.7918 & 0.2 & 0.4 & 21.3 & 12.7 & 1.7 \\
\hline Sherman Island II & 38.0452 & 121.8003 & 0.2 & 0.4 & 20.9 & 12.9 & 1.7 \\
\hline Brown & 38.0442 & 121.8739 & 0.4 & 2.7 & 20.8 & 12.7 & 2.0 \\
\hline Honker I & 38.0733 & 121.9230 & 0.9 & 2.7 & 19.8 & 12.6 & 3.1 \\
\hline Honker II & 38.0715 & 121.9338 & 1.2 & 2.7 & 19.3 & 12.7 & 2.0 \\
\hline Grizzly & 38.1175 & 122.0397 & 3.4 & 6.0 & 19.0 & 12.5 & 3.1 \\
\hline Suisun I & 38.0555 & 122.1200 & 8.3 & 10.2 & 19.7 & 12.3 & 3.0 \\
\hline Suisun II & 38.0915 & 122.0583 & 5.5 & 8.4 & 19.5 & 12.3 & 3.2 \\
\hline
\end{tabular}

The 2011 samples were collected on September 14, 2011 and September 16, 2011. The 2012 samples were collected on March 15, 2012 and March 17, 2012

Cores were shaded and kept in a water-filled cooler until transport to the Romberg Tiburon Center, Tiburon, CA, where the experiments were conducted. Upon return to the laboratory, each sediment core was bathed overnight in the overlying water from the respective site. A water-only control core was added to provide an estimate of water column effects on net fluxes. The cores were completely flushed to maintain $\mathrm{O}_{2}$ saturation, and the overnight pre-incubation allowed the cores time to come to a thermal equilibrium and to equilibrate the $\mathrm{N}_{2}, \mathrm{O}_{2}$, and $\mathrm{Ar}$ in the plastics with the water column.
To initialize flux experiments, a spinning top was installed on each core. All cores were then incubated in 5-7 h of darkness, followed, for a subset of the cores, by a $2-3-\mathrm{h}$ illuminated period using natural sunlight. Dark-only experiments were conducted on those cores that were collected from naturally turbid waters receiving little to no light at the sediment surface. Light incubations were added only for those cores collected from shallower sites that could receive light at the sediment surface. Dark incubation times were chosen to provide sufficient signal for nutrient concentration changes

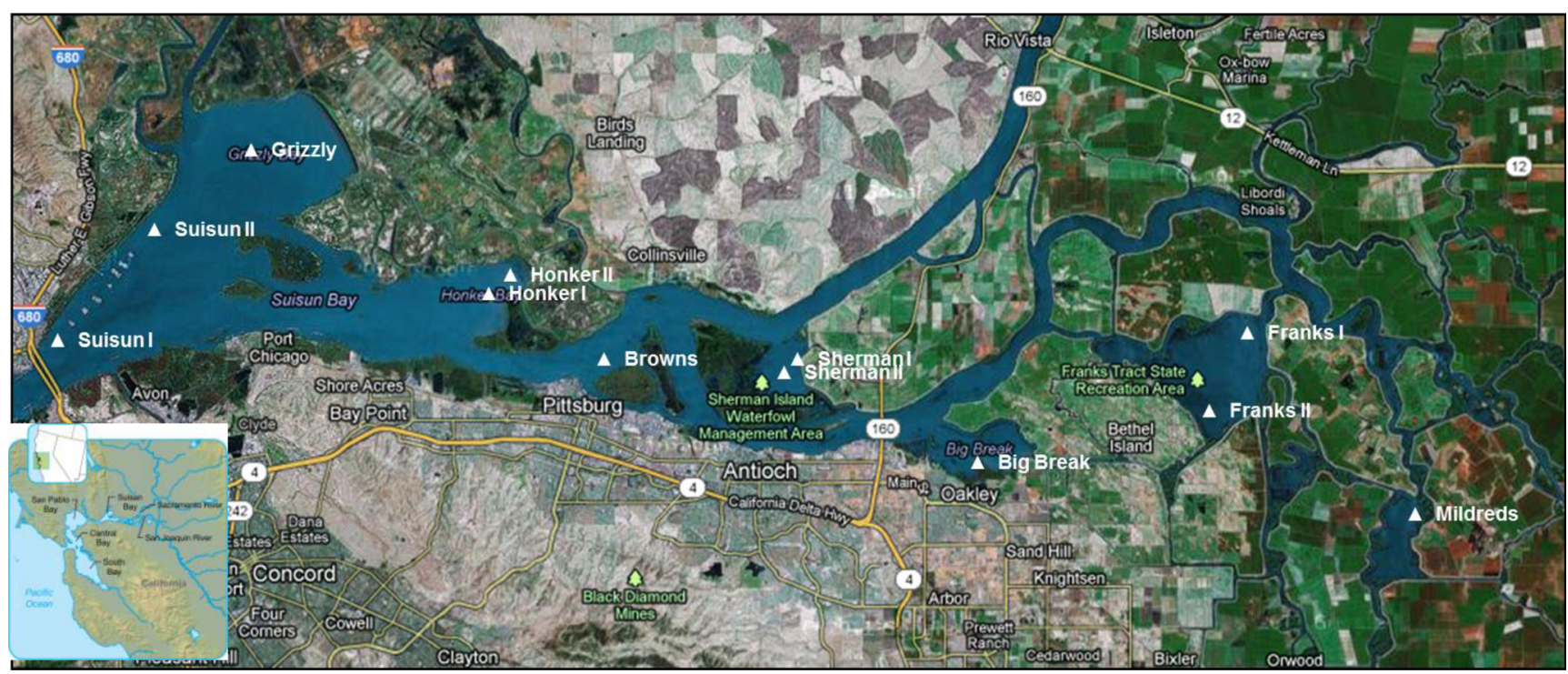

Fig. 1 Location map for San Francisco Bay Delta and enlarged map illustrating sampling sites for sediment flux work conducted during September 2011 and March 2012. Herein, we consider the Suisun I to
Browns set of six sites to be "Bay" sites and the Sherman Island to Mildred's Island sites to be "Delta" sites 
without depletion of $\mathrm{O}_{2}$ below $\sim 75 \%$ of saturation. Light incubation times were sufficient to measure changes without $\mathrm{O}_{2}$ supersaturation. Neutral density screening was used with natural sunlight to match the irradiances observed in the field (typically PAR values of 50-300 $\mathrm{mol} \mathrm{m}^{-2} \mathrm{~s}^{-1}$ ). During the March sediment incubations, heavy rains required that the incubations were carried out inside the SAV greenhouse area at the Tiburon Center; dark overcast conditions resulted in variable light levels.

Cores were sampled seven times during the incubation period, three times in the dark, once at the light/dark transition, and three times in the light, yielding a four-point time series for dark conditions and four-point time series for illuminated conditions. At each time point, samples of the overlying water were collected for dissolved $\mathrm{O}_{2}, \mathrm{~N}_{2}$, argon (Ar), SRP, $\mathrm{NH}_{4}{ }^{+}$, and $\mathrm{NO}_{3}{ }^{-}+\mathrm{NO}_{2}{ }^{-}$(also referred to as $\mathrm{NO}_{x}$ ). Samples for gas analysis of $\mathrm{N}_{2}, \mathrm{O}_{2}$, and $\mathrm{Ar}$ were collected in $7 \mathrm{~mL}$ glass stoppered vials with $10 \mu \mathrm{L}$ of $50 \%$ saturated $\mathrm{HgCl}_{2}$ added for preservation. Samples for nutrient analysis were collected in syringes, filtered ( $0.4 \mu \mathrm{m}$ polycarbonate filter), and frozen until analysis.

At the end of the incubation, the water volume overlying the sediments was measured and triplicated; samples for chlorophyll $a$ analysis were sub-cored from the surface $0-1 \mathrm{~cm}$ of each core using a cut-off syringe. Chlorophyll $a$ samples were immediately frozen to $-20^{\circ} \mathrm{C}$.

\section{Analytical Methodology}

Membrane inlet mass spectrometry (MIMS) was used for analysis of $\mathrm{O}_{2}, \mathrm{~N}_{2}$, and $\mathrm{Ar}$ (Kana et al. 1994). MIMS samples were analyzed by pumping the water through a membrane tube situated inside the mass spectrometer vacuum. Gas ratios (e.g., $\mathrm{N}_{2} / \mathrm{Ar}$ ) were measured with a precision of $<0.03 \%$ c.v. with minimal corrections for $\mathrm{O}_{2}$ depletion (Kana and Weiss 2004). Argon-normalized gas ratios were converted to gas concentrations using air equilibrated standards. Replicate analyses on the initial sampling (i.e., time zero) from each core were conducted.

Nutrient analysis was conducted using standard automated analysis techniques, with $\mathrm{NO}_{x}$ measured with $\mathrm{Cd}$ reduction. Chlorophyll $a$ was determined using acetone extraction according to Van Heukelem et al. (1994). These analyses were all carried out with $\sim 10 \%$ replication.

\section{Data Calculations}

Sediment-water exchange rates were calculated from the slope of the change of chemical constituent concentrations in the overlying water:

$F=\frac{\Delta C}{\Delta t} \times \frac{V}{A}$ where $F$ is the flux (micromoles per square meter per hour), $\Delta C / \Delta t$ is the slope of the concentration change in overlying water (micromoles per liter per hour), $V$ is the volume of the overlying water (liters), and $A$ is the area of the incubated core (per square meter). When the water-only control core had a significant slope, the slope of the flux cores was adjusted accordingly. Daily rates of nutrient exchange for the dark only conditions in Bay sediments were calculated by multiplying dark rates of flux by $24 \mathrm{~h}$; for Delta cores with illuminated time periods, the appropriate light/dark flux estimate was multiplied by the light/dark period length and summed.

\section{Benthic Microalgal Productivity Calculations}

The production of benthic microalgae was determined as the difference in $\mathrm{O}_{2}$ fluxes under illuminated and under dark incubation conditions. This implies that the rates of dark $\mathrm{O}_{2}$ flux represent a true measure of respiration and that dark and light rates of heterotrophic respiration are the same. Temporal changes in the depth distribution of redox processes resulting from diel changes in $\mathrm{O}_{2}$ penetration may affect net effluxes during changes from dark to light conditions (Hochard et al. 2010), though comparison of $\mathrm{O}_{2}$-based benthic microalgal photosynthesis to $\mathrm{CO}_{2}$-based estimates have shown good agreement (Newell et al. 2002). Daily rates of benthic microalgal production were calculated as the product of the photosynthetic rate and day length.

The variability between duplicate core flux rates differed for the analytes and was assessed as a coefficient of variability (COV) using half the range between cores divided by the absolute value of the average flux rate. Median $\mathrm{O}_{2}$ and $\mathrm{N}_{2}-\mathrm{N}$ duplicate core variability was $12 \%$ for rates less than -500 and $40 \mu \mathrm{mol} \mathrm{m} \mathrm{m}^{-2} \mathrm{~h}^{-1}$, respectively, increasing three- to fivefold for slower rates. Median SRP, $\mathrm{NO}_{x}$, and $\mathrm{NH}_{4}{ }^{+} \mathrm{COVs}$ ranged from 31 to $34 \%$ for absolute value rates greater than 10,20 , and $40 \mu \mathrm{mol} \mathrm{m} \mathrm{m}^{-2} \mathrm{~h}^{-1}$ respectively, increasing more than threefold for lower rates.

\section{Statistical Tests}

A two-way analysis of variance was carried out on the flux and sediment chlorophyll $a$ data using the Sigmaplot statistical package (Version 11, Systat Software, Inc.). Under dark conditions, comparisons were made for each parameter, examining the data for differences between Delta and Bay environments, and March and September time periods. For the illuminated Delta sediments, we compared dark versus light conditions. Significance was accepted for $P<0.05$. 


\section{Results}

\section{Ambient Environmental Conditions}

The sampled sites encompassed regions from $<1$ to 10.2 salinity (Table 1). All sites had depths $\leq 3.2 \mathrm{~m}$ at the time of sampling. Temperatures varied across sites by up to $3.2{ }^{\circ} \mathrm{C}$ in September $\left(19.5-22.2^{\circ} \mathrm{C}\right)$, but a much smaller temperature gradient $\left(12.3-13.3{ }^{\circ} \mathrm{C}\right.$ ) across sites was observed in March (Table 1). September concentrations of $\mathrm{NO}_{x}$ were $<5 \mu \mathrm{mol} \mathrm{L}{ }^{-1}$ in Delta sites other than Sherman Lake, while Sherman Lake and Bay concentrations were 17-22 $\mu \mathrm{mol} \mathrm{L}{ }^{-1}$. In March, all Bay and Delta sites had $\mathrm{NO}_{x}$ concentrations of 40-43 $\mu \mathrm{mol} \mathrm{L}{ }^{-1}$.

\section{Nitrogen Fluxes}

With few exceptions, virtually all cores from all sites, both Delta and Bay, exhibited net effluxes of $\mathrm{N}_{2}-\mathrm{N}$ or denitrification (Fig. 2). The dark $\mathrm{N}_{2}-\mathrm{N}$ fluxes averaged $34 \pm$ $30 \mu \mathrm{mol} \mathrm{m}{ }^{-2} \mathrm{~h}^{-1}$ with a median of $32 \mu \mathrm{mol} \mathrm{m} \mathrm{m}^{-2} \mathrm{~h}^{-1}$ in September and $48 \pm 31 \mu \mathrm{mol} \mathrm{m} \mathrm{m}^{-2} \mathrm{~h}^{-1}$ with a median rate of $48 \mu \mathrm{mol} \mathrm{m} \mathrm{m}^{-2} \mathrm{~h}^{-1}$ in March; these temporal differences were not significant (see ANOVA results in Table 2). The Bay denitrification rates were significantly lower $(P<0.05)$ than Delta rates, and within the Delta, dark rates were significantly $(P<0.05)$ greater than light rates.

Fluxes of $\mathrm{NO}_{x}$ were generally directed into the sediments in March and out of the sediment during September (Fig. 3). Spatially, most of the sites in the Delta (Sherman Island excepted) had $\mathrm{NO}_{x}$ fluxes directed into the sediments during both seasons, whereas the flux was in the opposite direction at the Bay sites. Overall, March $\mathrm{NO}_{x}$ fluxes were less than September fluxes and Bay fluxes were greater than Delta fluxes $(P<0.05)$. Fluxes in the light were not significantly different than dark fluxes.

Fluxes of $\mathrm{NH}_{4}{ }^{+}$(Fig. 4) were higher in September than in spring $(P<0.05)$. Spatially, the fluxes of $\mathrm{NH}_{4}{ }^{+}$generally exhibited the opposite pattern to those of $\mathrm{NO}_{x}$ : although a number of the highest effluxes occurred in the Delta sites with highest influxes at the Bay sites, Bay and Delta environments were not statistically different. Lower flux rates (i.e., high rates of $\mathrm{NH}_{4}^{+}$uptake) were measured under illuminated conditions in both September (Sherman Island I) and March (Franks Tract I, Big Break). Under dark conditions, 8 of the 12 measured sites appeared to be important sources of $\mathrm{NH}_{4}{ }^{+}$, with a substantial amount of benthic microalgal attenuation of $\mathrm{NH}_{4}{ }^{+}$effluxes at four of these sites.

\section{Phosphorus Fluxes}

Overall trends in SRP fluxes were similar in direction to those of $\mathrm{NH}_{4}^{+}$(Fig. 5). Higher rates were generally observed in
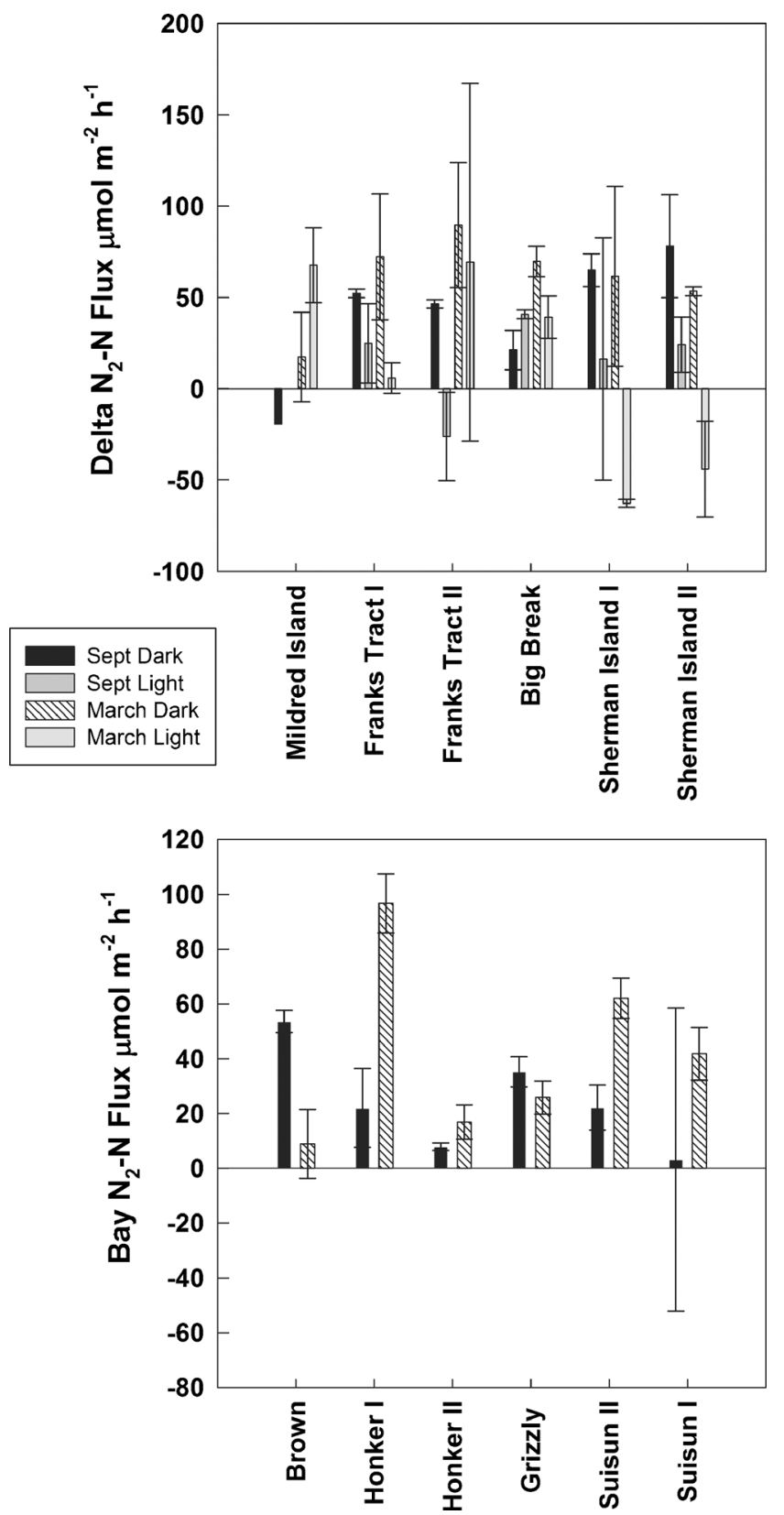

Fig. 2 Sediment-water exchange rates of $\mathrm{N}_{2}-\mathrm{N}$ (di-nitrogen). Data include dark fluxes for all sites and light ("illuminated") flux incubations for sites when light reaches the sediment surface. Each bar is the mean of duplicate cores, and error bars show the data range (except for the March 2012 data at Big Break where $N=6$ and error bars are the standard deviation). Negative rates are likely incubation artifacts that are most commonly observed in sediments with benthic microalgal production. Positive rates indicate a flux directed from the sediment to the water column. For the September sampling, Mildred I had no illuminated data

March than in September $(P<0.05)$, and there was a greater tendency for efflux in the Delta compared to the Bay $(P<0.05)$. Overall, dark fluxes were less than light fluxes $(P<0.05)$. SRP fluxes under illumination were directed into the sediment, with particularly high $\left(>10 \mu \mathrm{mol} \mathrm{m} \mathrm{m}^{-2} \mathrm{~h}^{-1}\right)$ rates observed in March at Mildred Island, Franks Tract II, Big 
Table 2 ANOVA results for sediment-water exchange and chlorophyll measurements

\begin{tabular}{llll}
\hline $\begin{array}{l}\text { Flux } \\
\text { parameter }\end{array}$ & $\begin{array}{l}\text { Dark fluxes by } \\
\text { season (March vs } \\
\text { September) }\end{array}$ & $\begin{array}{l}\text { Dark Fluxes By } \\
\text { Location (Delta } \\
\text { vs Bay) }\end{array}$ & $\begin{array}{l}\text { Delta Only By } \\
\text { Illumination (dark } \\
\text { vs light) }\end{array}$ \\
\hline $\mathrm{N}_{2}-\mathrm{N}$ & $\mathrm{ns}$ & Bay $<$ Delta & Dk $>$ Lt \\
$\mathrm{NO}_{x}$ & Mar $<$ Sept & Bay $>$ Delta & ns \\
$\mathrm{NH}_{4}{ }^{+}$ & Mar $<$Sept & - & Dk $>$Lt \\
$\mathrm{SRP}$ & Mar $>$ Sept & Bay $<$ Delta & Dk $>$ Lt \\
$\mathrm{O}_{2}$ & Mar $<$ Sept & Bay $<$ Delta & Dk $<$ Lt \\
Chlorophyll & ns & Bay $<$ Delta & na \\
\hline
\end{tabular}

Significant differences $(P<0.05)$ in fluxes are indicated by $<$ or $>$ symbols, ns is non-significant, and na is non-applicable

Break, and Sherman I and II. Moreover, in March, dark SRP fluxes had a distinct spatial pattern, with moderate to large effluxes in Mildred to Big Break, large rates of uptake in Sherman Island, moderate efflux at Brown, and minimal flux at Honker, Grizzly, and Suisun sites.

\section{Oxygen Fluxes and Sediment Chlorophyll $a$}

Fluxes of $\mathrm{O}_{2}$ in aquatic sediments are the summation of direct uptake of $\mathrm{O}_{2}$ during anaerobic sediment decomposition, uptake during re-oxidation of reduced species (e.g., sulfides, $\mathrm{Fe}(\mathrm{II}), \mathrm{NH}_{4}^{+}$), and autotrophic $\mathrm{O}_{2}$ production by benthic microalgae. Dark uptake of $\mathrm{O}_{2}$ was observed at all sites (Fig. 6). On a seasonal basis, higher $\mathrm{O}_{2}$ flux rates were observed at all sites during the September sample period compared to March $(P<0.05)$. This is consistent with increased sediment metabolic rates as temperature increased to 19-22 ${ }^{\circ} \mathrm{C}$ in September from $12-13{ }^{\circ} \mathrm{C}$ in March (Table 1). Large spatial differences were observed, with higher average dark $\mathrm{O}_{2}$ uptake in Delta sediments than in Bay sediments $(P<0.05)$.

Significantly higher rates of benthic photosynthesis $(P<0.05)$ were calculated in September (range $=393-$ $1,924 \mu \mathrm{mol} \mathrm{O}{ }_{2} \mathrm{~m}^{-2} \mathrm{~h}^{-1}$; mean, $1,029 \pm 628 \mu \mathrm{mol} \mathrm{O}_{2} \mathrm{~m}^{-2} \mathrm{~h}^{-1}$ ) than in March (range $=144-498 \mu \mathrm{mol} \mathrm{O}_{2} \mathrm{~m}^{-2} \mathrm{~h}^{-1}$; mean, 115 $\left.\pm 33 \mu \mathrm{mol} \mathrm{O} \mathrm{m}^{-2} \mathrm{~h}^{-1}\right)$. These values should be considered as broad estimates only as cores were exposed to single light levels only, and ambient light levels varied between seasons. The concentrations of sediment chlorophyll $a$ were significantly higher $(P<0.05)$ in Delta sediments compared to Bay sediments (Fig. 7), but seasonal differences were not significant.

\section{Discussion}

The measurements reported here represent the first seasonal comparison of comprehensive nutrient fluxes from sediments
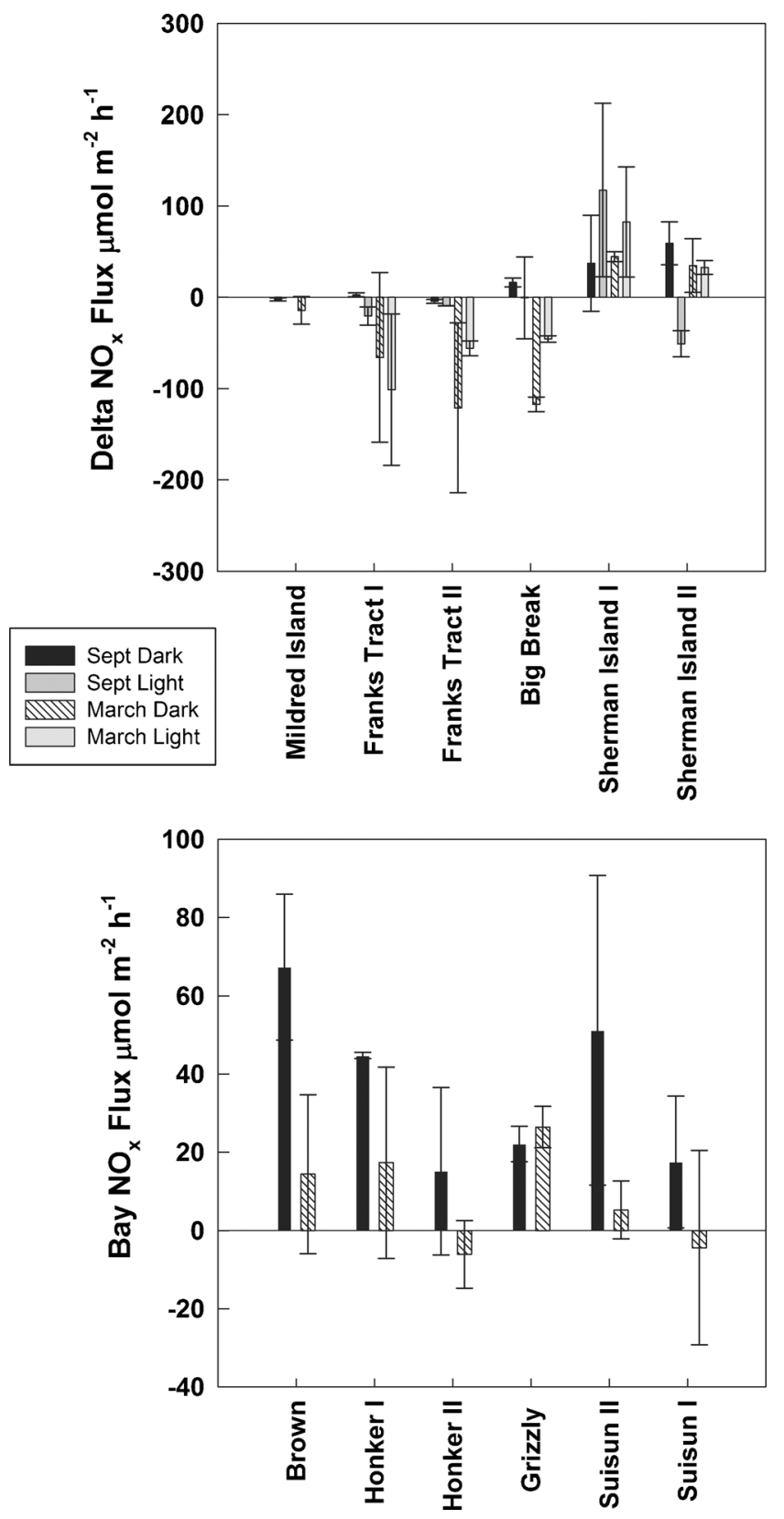

Fig. 3 Sediment-water exchange rates of $\mathrm{NO}_{x}{ }^{-}$(i.e., the sum of nitrate and nitrite). Data include dark fluxes for all sites and light ("illuminated") flux incubations for sites when light reaches the sediment surface. Each bar is the mean of duplicate cores, and error bars show the data range (except for the March 2012 data at Big Break where $N=6$ and error bars are the standard deviation). Positive rates indicate a flux directed from the sediment to the water column. For the September sampling, Mildred I had no illuminated data

in the San Francisco Bay Delta. Here, we discuss these rates in the context of available data for regionally similar estuaries and for estuaries and coasts worldwide, differential regulation of stoichiometry of the fluxes across the gradient of sites measured, and, finally, the potential contribution of these rates to overall Bay Delta productivity and nutrient loads. 

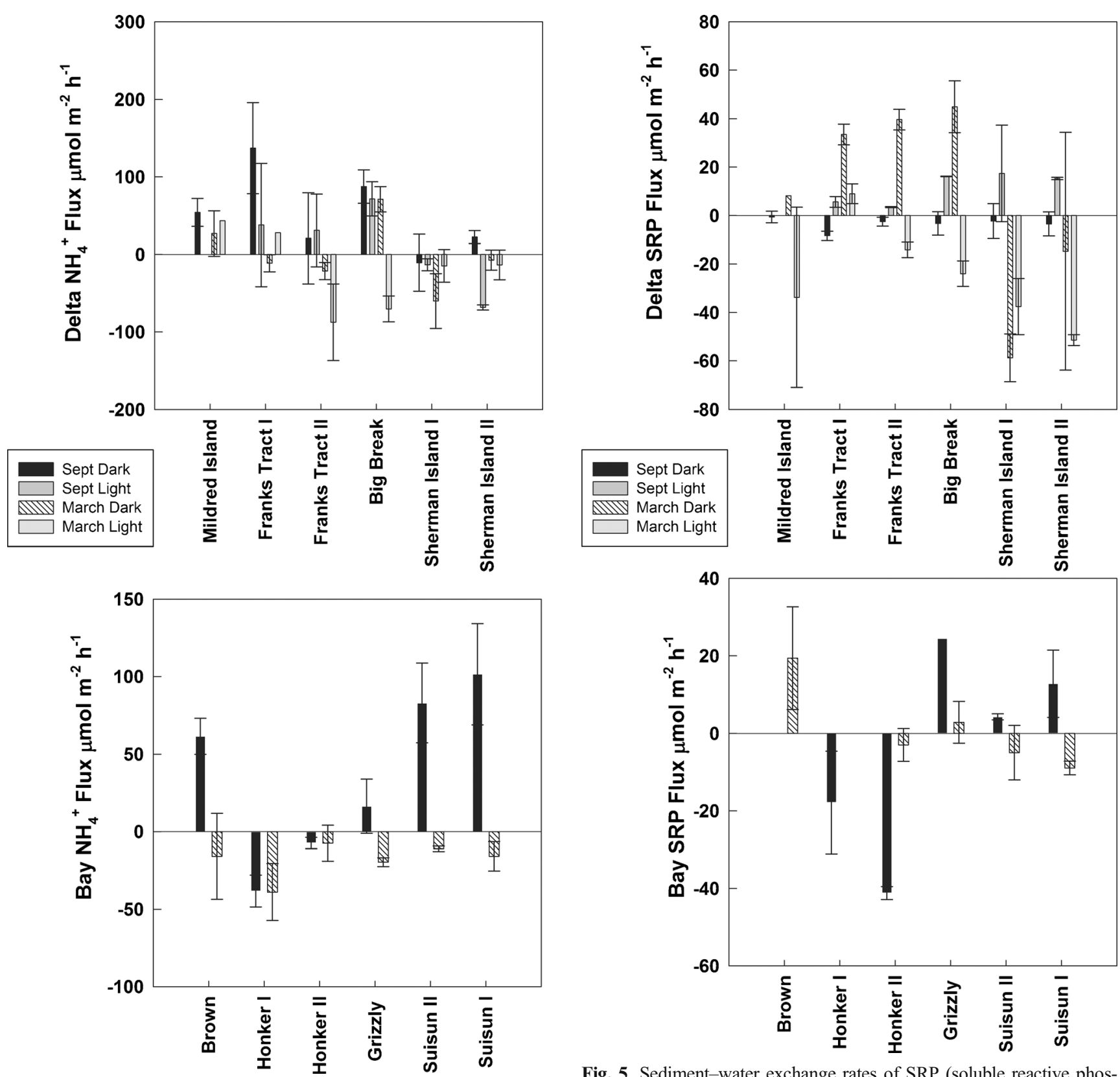

Fig. 4 Sediment-water exchange rates of $\mathrm{NH}_{4}{ }^{+}$. Data include dark fluxes for all sites and light ("illuminated") flux incubations for Delta sites when light reaches the sediment surface. Each bar is the mean of duplicate cores, and error bars show the data range (except for the March 2012 data at Big Break where $N=6$ and error bars are the standard deviation). Positive rates indicate a flux directed from the sediment to the water column. For the September sampling, Mildred I had no illuminated data

\section{Measured Rates in a Regional and Global Context}

Fluxes of $\mathrm{N}$ were directed both into and out of the sediments and both direction and magnitude varied as a result of the multiple processes contributing to such fluxes, including denitrification, nitrification, assimilation by benthic microalgae, and dissimilatory reduction of $\mathrm{NO}_{3}{ }^{-}$to $\mathrm{NH}_{4}^{+}$(DNRA), as well as a broad range of organic matter loading to the different sediments

Fig. 5 Sediment-water exchange rates of SRP (soluble reactive phosphorus). Data include dark fluxes for all sites and light ("illuminated") flux incubations for sites when light reaches the sediment surface. Each bar is the mean of duplicate cores, and error bars are show the data range (except for the March 2012 data at Big Break where $N=6$ and error bars are the standard deviation). Positive rates indicate a flux directed from the sediment to the water column. For the September sampling, Mildred I had no illuminated data

tested. When compared to previous measured rates of denitrification worldwide compiled by Joye and Anderson (2008) using similar MIMS techniques, the rates measured herein are comparable to most other estuaries (Table 3). Uptake rates of $\mathrm{NO}_{x}$ in the upper Delta are much higher than observed in other northern California sites such as Tomales Bay, but similar rates have previously been reported in the $\mathrm{NO}_{x}$-enriched Elkhorn Slough (Dollar et al. 1991; Caffrey et al. 2002). $\mathrm{The}^{\mathrm{NH}_{4}}{ }^{+}$ 


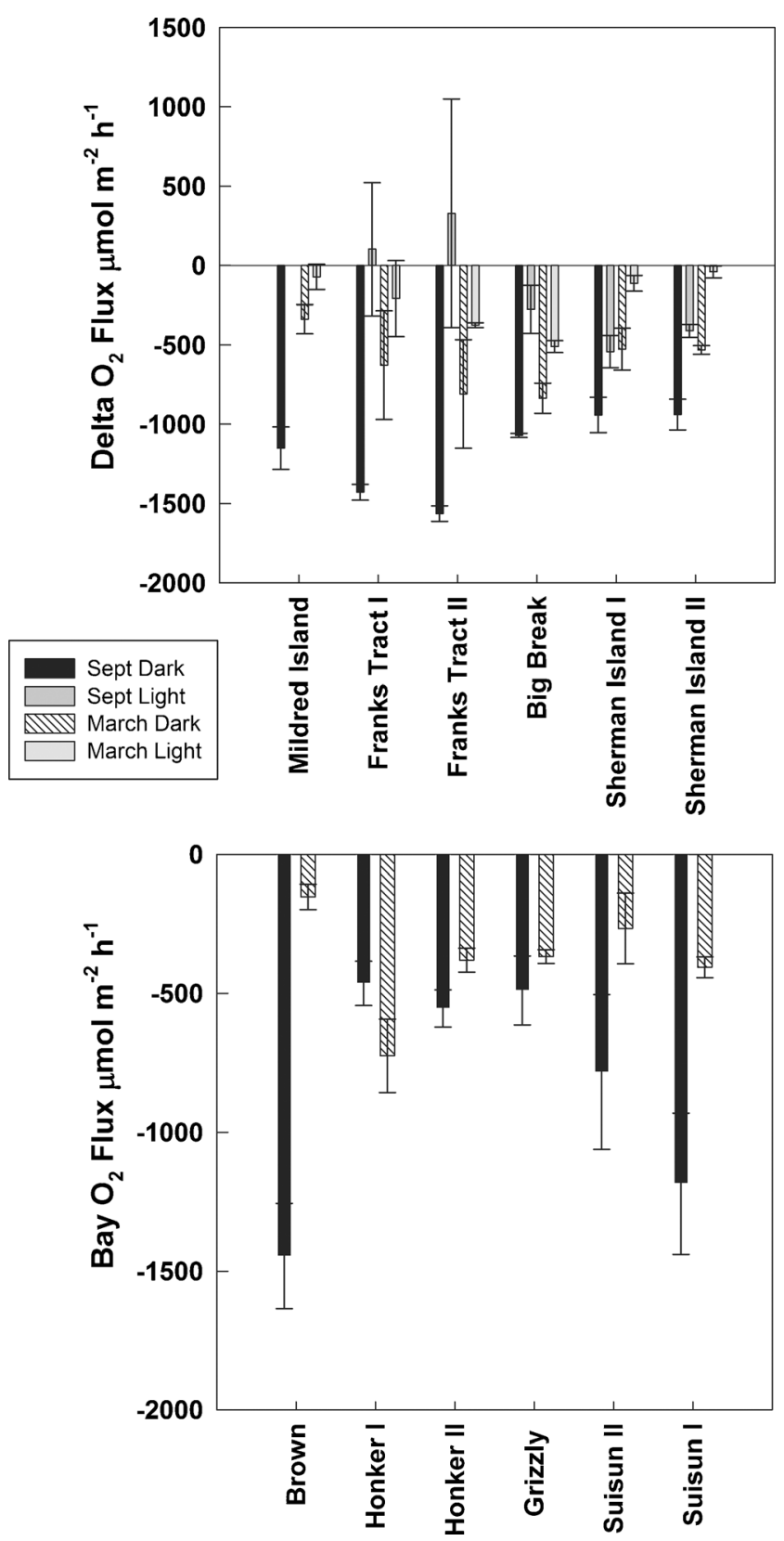

Fig. 6 Sediment-water exchange rates of oxygen for Delta (top panel) and Bay (bottom panel) environments. Data include dark fluxes for all sites and light ("illuminated") flux incubations for Delta sites where light reaches the sediment surface. Each bar is the mean of duplicate cores, and error bars show the data range (except for the March 2012 data at Big Break where $N=6$ and error bars are the standard deviation). Positive rates indicate a flux directed from the sediment to the water column. For the September sampling, Mildred I had no illuminated data

effluxes in the Delta-Bay transect had most effluxes $<100 \mu \mathrm{mol} \mathrm{m} \mathrm{m}^{-2} \mathrm{~h}^{-1}$, with many sites showing uptake in the light and occasionally in the dark. In the Bay Delta region, Caffrey (1995) reported net $\mathrm{NH}_{4}{ }^{+}$production rates at Rio Vista and Suisun Bay that were $<100 \mu \mathrm{mol} \mathrm{m} \mathrm{m}^{-2}$ at all seasons. However, regionally, $\mathrm{NH}_{4}{ }^{+}$flux rates measured in Tomales Bay and Elkhorn Slough were somewhat higher than our observations (Dollar et al. 1991; Caffrey et al. 2002, 2010). Boynton and Kemp (2008) also compiled a comparative data set of dark $\mathrm{NH}_{4}{ }^{+}$effluxes for many estuaries, and these values also showed most effluxes $<100 \mu \mathrm{mol} \mathrm{m}{ }^{-2} \mathrm{~h}^{-1}$.

Similar to previously reported data for Elkhorn Slough and Tomales Bay (Caffrey et al. 2002), the SRP fluxes in the BayDelta transect had large rates of efflux and influx. The only previously available study on benthic fluxes nutrients in the upper Bay Delta in late summer reported $\mathrm{P}$ efflux rates that ranged from insignificant to $\sim 0.06 \mathrm{mmol} \mathrm{m}^{2} \mathrm{day}^{-1}$, considerably lower than rates previously found for the more saline reaches of the estuary and considerably lower than those of $\mathrm{NH}_{4}{ }^{+}$(Kuwabara et al. 2009). The SRP efflux rates reported herein are significantly higher than those of Kuwabara et al. (2009), but different methodologies were applied in these two studies. In Tomales Bay, California, USA, Chambers et al. (1995) estimated that release of particle-bound $\mathrm{P}$ was $\sim 12 \%$ of the benthic flux of P in sediments that were sulfide-rich. In their global comparison, Boynton and Kemp (2008) showed that roughly one in ten dark SRP flux measurements had a net uptake of SRP into the sediment, indicating that SRP uptake is not uncommon in estuarine sediments. In fact, of the 228 studies they summarized in which SRP fluxes were measured for sediments $<5 \mathrm{~m}$ depth, the SRP fluxes for the Bay Delta were in the upper range, if not exceeding these previous studies. In the Bay Delta, where P was previously measured in the upper few centimeters of sediment, concentrations were 5-10 $\mu \mathrm{mol} \mathrm{g}^{-1}$ in the confluence region, but significantly higher at freshwater sites (Nilsen and Delaney 2005). It has been suggested that localized regions of high benthic productivity may result in elevated $\mathrm{pH}$ which, in turn, may result in a change in SRP fluxes, from influx to efflux (Glibert et al. 2011; Gao et al. 2012). That higher efflux of SRP was observed in all Bay Delta sites would be consistent with this hypothesis.

Coastal and estuarine sediments with benthic microalgae have a broad range of chlorophyll $a$ concentrations, ranging up to $560 \mathrm{mg} \mathrm{m}^{-2}$ (MacIntyre et al. 1996); the highest chlorophyll $a$ concentrations measured in this study were found in September at Franks Tract I (replicate cores with 66 and $91 \mathrm{mg} \mathrm{m}^{-2}$; Fig. 7). The sediment chlorophyll $a$ data reported here compared favorably, on average, with those previously reported by Kuwabara et al. (2009), but there were spatial differences. As an example, at Sherman Island, the data reported here are much higher than Kuwabara et al.'s (2009) observations that showed no detectable chlorophyll $a$; based on single analyses from four cores during each season, the average observed during this study was $14 \pm 3$ and $10 \pm$ $4 \mathrm{mg} \mathrm{m}^{-2}$ chlorophyll $a$ in September and March. Dark sediment $\mathrm{O}_{2}$ fluxes were $<2000 \mu \mathrm{mol} \mathrm{m} \mathrm{m}^{-2} \mathrm{~h}^{-1}$, a number consistent with estuarine observations worldwide (Boynton and Kemp 2008). The highest rate of $\mathrm{O}_{2}$ uptake are similar to 


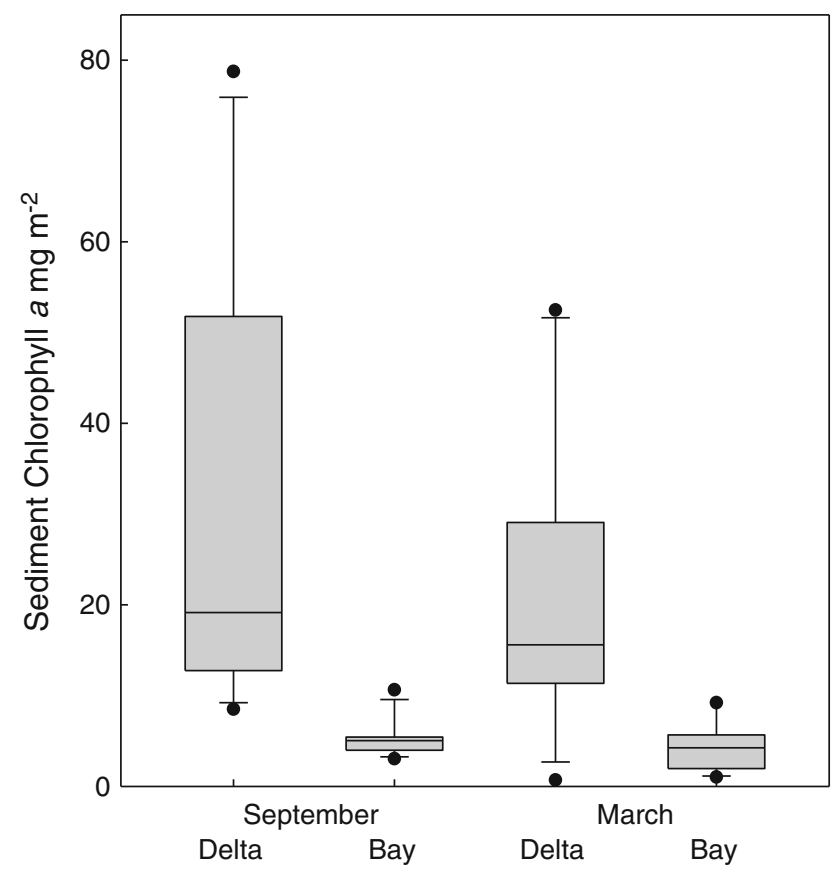

Fig. 7 Sediment chlorophyll $a$ concentrations from Delta and Bay environments in September 2011 and March 2012. The box plots show the median as the line within the box, the box represents the 25-75th percentiles, and the error bars are the $0-25$ and $75-100$ percentiles. A Kruskal-Wallis one-way analysis of variance on ranks showed that the Delta and Bay locations were significantly different $(P<0.01)$ and that there were no temporal differences

those in nearby Tomales Bay (Dollar et al. 1991), with the Tomales Bay annual average $\mathrm{O}_{2}$ uptake similar to the March 2012 rates reported herein.

\section{Elemental Stoichiometry of Fluxes}

The rates of $\Sigma \mathrm{N}$ flux $\left(\Sigma \mathrm{N}=\mathrm{NH}_{4}{ }^{+}+\mathrm{NO}_{x}{ }^{-}+\mathrm{N}_{2}-\mathrm{N}\right.$ flux $)$ can be compared to sediment $\mathrm{O}_{2}$ demand to examine the stoichiometric relationship of $\mathrm{N}$ flux to organic matter decomposition. Implicit in this analysis is that (1) organic matter sources have a reasonably similar composition, with Redfield algal organic matter used as a key metric, (2) microbial processes yield remineralized $\mathrm{N}$ and $\mathrm{P}$ in expected ratios, and (3) $\mathrm{O}_{2}$ fluxes are a suitable measure of metabolism. Sediment $\mathrm{O}_{2}$ demand has the opposite sign of $\mathrm{O}_{2}$ fluxes and while an imperfect measure of metabolism (Banta et al. 1994), provides a useful comparison to nutrient fluxes.

In September, $\Sigma \mathrm{N}$ fluxes generally increased with increasing sediment $\mathrm{O}_{2}$ demand, with the greatest scatter in the light fluxes from Delta sediments (Fig. 8). In March, the agreement with stoichiometry was much weaker, with illuminated Delta sediments showing a $\Sigma \mathrm{N}$ deficit while dark Delta sediments showed a $\mathrm{N}$ excess. The balance of $\mathrm{N}$ on a diel cycle may better reflect the true net balance of these Delta sites. In March, the bay sediments appeared to follow stoichiometry much more closely. The September flux of SRP relative to $\mathrm{O}_{2}$
Table 3 Compilation of rates of denitrification measured in estuaries and coastal regions worldwide

\begin{tabular}{|c|c|c|}
\hline $\begin{array}{l}\text { Estuary or } \\
\text { coastal region }\end{array}$ & $\begin{array}{l}\text { Denitrification } \\
\text { rate }\left(\mathrm{mmol} \mathrm{m} \mathrm{m}^{-2}\right. \\
\left.\text { day }^{-1}\right)\end{array}$ & Reference \\
\hline & & Kana et al. (1998) \\
\hline \multirow[t]{2}{*}{ Laguna Madre, TX } & 0.48 & An et al. (2001) \\
\hline & $0.2-0.98$ & An and Gardner (2002) \\
\hline Mid-Atlantic Bight & 1.74 & $\begin{array}{l}\text { Laursen and } \\
\text { Seitzinger (2002) }\end{array}$ \\
\hline Chesapeake Bay & $5.4-12$ & Newell et al. (2002) \\
\hline Baffin Bay, TX & $0.4-1.63$ & An and Gardner (2002) \\
\hline Lagoons, Sydney, AU & $0.19-1.66$ & Eyre and Ferguson (2002) \\
\hline $\begin{array}{l}\text { Readings Bay, New } \\
\text { Brunswick, AU }\end{array}$ & $1.2-7.2$ & Webb and Eyre (2004) \\
\hline Bremer River, AU & 3.78 & Cook et al. (2004b) \\
\hline Huon Estuary, AU & $0.01-0.12$ & Cook et al. (2004a) \\
\hline \multirow[t]{2}{*}{ Brunswick Estuary, AU } & $0.38-5.95$ & Ferguson et al. (2004) \\
\hline & $0.07-1.4$ & Eyre and Ferguson (2005) \\
\hline Neuse River Estuary, NC & $0-6.62$ & Fear et al. (2005) \\
\hline Matagorda Bay, TX & $0.54+0.1$ & Gardner et al. (2006) \\
\hline Nueces Estuary, TX & $0.96 \pm 0.2$ & Gardner et al. (2006) \\
\hline Sapelo Island, GA & $0.1-0.2$ & Porubsky et al. (2009) \\
\hline Dover Bluff, GA & $0-0.4$ & Porubsky et al. (2009) \\
\hline Okatee Estuary, SC & $0-0.2$ & Porubsky et al. (2009) \\
\hline Randers Fjord, DK & $5.2-8.0$ & $\begin{array}{l}\text { Risgaard-Petersen } \\
\text { et al. (2004) }\end{array}$ \\
\hline Norsminde Fjord, DK & $4.6-5.7$ & $\begin{array}{l}\text { Risgaard-Petersen } \\
\text { et al. (2004) }\end{array}$ \\
\hline Delta sites & $0.7-0.9$ & This study \\
\hline Bay sites & $0.6-1.0$ & This study \\
\hline
\end{tabular}

All rates reported here were determined using MIMS methodology. This compilation is a subset of all denitrification rates reported by Joye and Anderson (2008). For our Delta sites, we used day length to determine a daily denitrification rate from our light and dark incubations, the range represents the data from the two sample times

demand generally showed that dark incubations tended to have a SRP deficit, while illuminated sediments had SRP fluxes slightly in excess of stoichiometry. In March, illuminated sediment showed a SRP deficit relative to $\mathrm{O}_{2}$ uptake, suggesting excess SRP uptake beyond nutritional requirements.

Overall, the lack of tight relationships between observed and expected $\mathrm{C} / \mathrm{N} / \mathrm{P}$ suggests that controls beyond the rates of organic matter remineralization are important. Nitrification and denitrification change dissolved inorganic $\mathrm{N}$ effluxes, but conserved stoichiometry is not observed, even when $\mathrm{N}_{2}-$ $\mathrm{N}$ fluxes are considered. Such conservation of ratios would not necessarily be expected (Glibert et al. 2011). Benthic microalgae can skew elemental ratios by "luxury" uptake during periods without light and by intercepting remineralized $\mathrm{N}$ and P. Stoichiometric relationships for SRP are affected by 


\section{September}
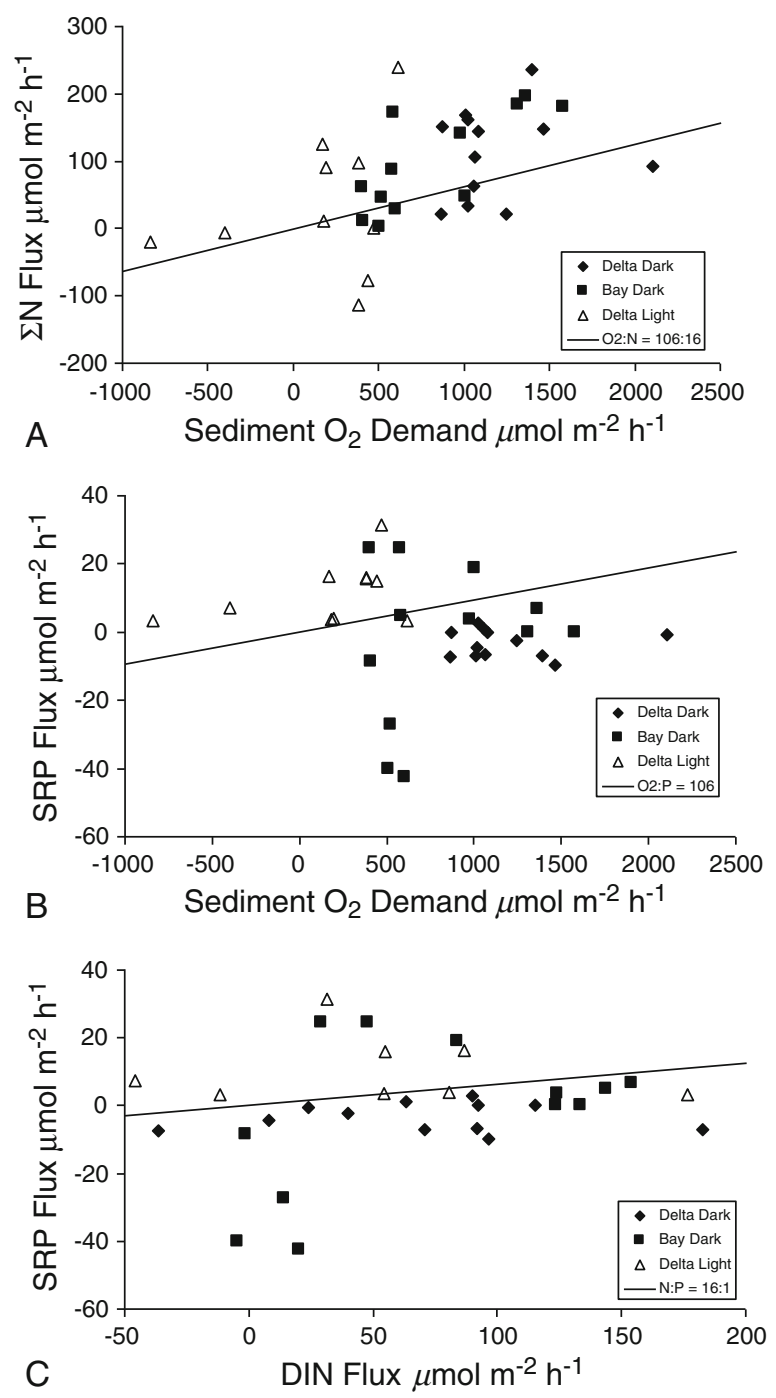

Fig. $8 A-C$ September 2011 property plots of sediment-water exchange; sediment oxygen demand has the opposite sign of oxygen fluxes, with negative values for net photosynthetic fluxes. Data include bay stations and both light and dark incubations of Delta sediments. $A$ shows a plot of sediment oxygen demand versus $\Sigma \mathrm{N}$ flux $\left(\mathrm{N}_{2}-\mathrm{N}+\mathrm{NH}_{4}{ }^{+}+\mathrm{NO}_{x}\right)$ showing general agreement, with $\mathrm{N}$ efflux in excess of the Redfield ratio.

SRP retention/release on the surface of iron oxide minerals; the predominance of inorganic forms of $\mathrm{P}$ in these sediments (Nilsen and Delaney 2005) can result in (1) P retention and (2) possible release under low redox conditions (Lehtoranta et al. 2009), changes in salinity (Froelich 1988; Gardolinski et al. 2004), and changes in $\mathrm{pH}$ (Glibert et al. 2011; Gao et al. 2012).

The salinity gradient encompassed in this study did not show consistent large differences in sediment $\mathrm{N}$ or $\mathrm{P}$ biogeochemistry, although stoichiometric changes along the salinity gradient were expected and observed. Three Bay sites had significant $P$ retention relative to DIN, while all the Delta sites from the light experiments had excess $\mathrm{P}$ release relative to $\mathrm{N}$.
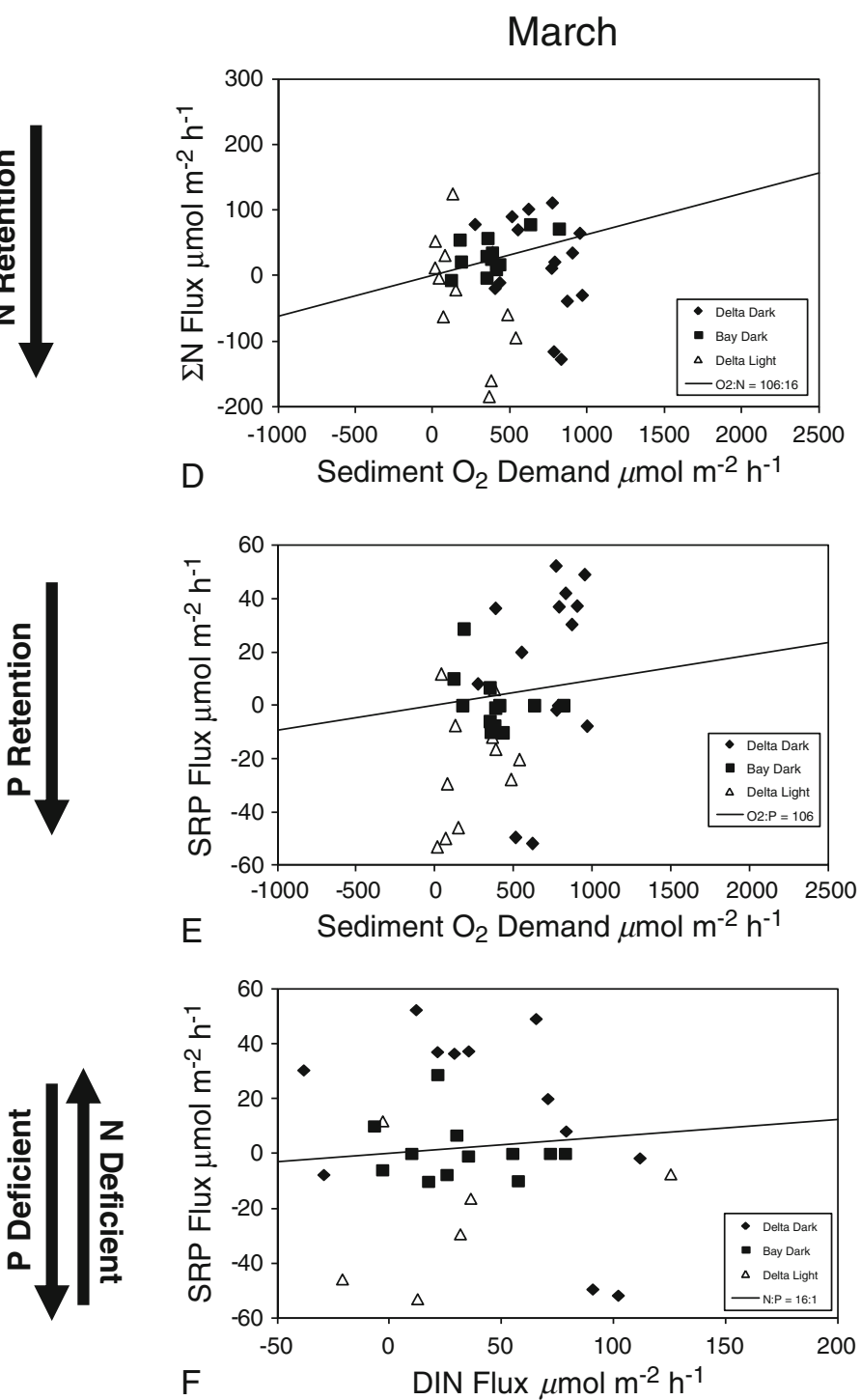

The SRP fluxes below the Redfield line in $B$ indicate a net retention of organic P within the sediments. The SRP versus DIN plot $(\boldsymbol{C})$ indicates that SRP is generally lower than predicted by stoichiometry, suggesting that during sediment nutrient recycling that $\mathrm{N}$ is generally in excess of $\mathrm{P}$. $D-F$ : As for $A-C$ except for March 2012

Large differences along the spatial (salinity) gradient were also observed in the form of $\mathrm{N}$ flux, i.e., the ratio of $\mathrm{NO}_{x} /$ $\mathrm{NH}_{4}^{+}$. Salinity generally has an opposite effect on $\mathrm{N}$ fluxes compared to $\mathrm{P}$ fluxes. Whereas $\mathrm{P}$ flux rates are often higher in saltwater, rates of $\mathrm{NH}_{4}^{+}$flux are higher in freshwater (Jordan et al. 2008 and references therein), and this can accentuate the discrepancy between N/P ratios along the salinity gradient, and indeed the patterns herein are consistent with this generally expected pattern. Consistent with this idea, comparisons of the $\mathrm{NH}_{4}{ }^{+} / \mathrm{PO}_{4}{ }^{3-}$ ratio along the salinity gradient of four sub-estuaries of Chesapeake Bay (Patuxent, Potomac, Choptank, and Bush Rivers) also revealed in common a switch from molar ratios $>16$ to $<16$ as salinity increased, 
Table 4 Summary of total net N input for the length of Sacramento (SAC) and San Joaquin Rivers (SJR) indicated

\begin{tabular}{|c|c|c|c|c|c|}
\hline & $\begin{array}{l}\text { Total area } \\
\left(\mathrm{km}^{-2}\right)\end{array}$ & $\begin{array}{l}\text { River TN yield } \\
\left(\mathrm{kg} \mathrm{N} \mathrm{km}^{-2} \text { year }^{-1}\right)\end{array}$ & $\begin{array}{l}\text { Daily TN yield } \\
\left(\mathrm{kg} \mathrm{N} \mathrm{km}^{-2} \text { day }^{-1}\right)\end{array}$ & $\begin{array}{l}\text { Total daily net TN yield } \\
\left(\mathrm{kg} \mathrm{N} \mathrm{day}^{-1}\right)\end{array}$ & $\begin{array}{l}\text { Total daily net } \mathrm{N} \text { yield } \\
\text { (tonnes } \mathrm{N} \mathrm{day}^{-1} \text { ) }\end{array}$ \\
\hline SAC & 61,721 & 126 & 0.35 & 21,602 & 21 \\
\hline SJR & 19,030 & 135 & 0.36 & 6,851 & 6.8 \\
\hline
\end{tabular}

All data are based on values from the early 2000s, as reported by Sobota et al. (2009)

with a major breakpoint in the salinity range of 1-4 (Hartzell et al. 2010). Seitzinger et al. (1991b) suggested that lower denitrification efficiencies in saltwater compared to freshwater arise, at least in part, due to decreased adsorption of $\mathrm{NH}_{4}{ }^{+}$at higher ionic strengths which leads to poor efficiency of nitrification.

\section{Potential Delta Impact}

Estimated benthic microalgal productivity was surprisingly high in Delta sediments, with a large range in both biomass and productivity. The median rates of $\mathrm{O}_{2}$-based photosynthesis estimated here were 795 and $395 \mu \mathrm{mol} \mathrm{O}_{2} \mathrm{~m}^{-2} \mathrm{~h}^{-1}$ for September and March, respectively; these data are equivalent to 119 and $57 \mathrm{mg} \mathrm{C} \mathrm{m}^{-2}$ day $^{-1}$ for the day length at each sample period. While these rates are estimates and more detailed measurements as a function of irradiance are required, these rates are similar to benthic microalgal photosynthetic rates observed in a wide range of coastal environments (MacIntyre et al. 1996). Guarini et al. (2002) examined potential productivity in San Francisco Bay tidal environments using resuspended benthic algae and a modeling extrapolation, concluding that spatial variation in benthic productivity would be large, but measured no in situ or ex situ benthic microalgal production.

Jassby et al. (2002) modeled phytoplankton production in the River Delta with a predicted annual range of 24-131 g $\mathrm{C} \mathrm{m}^{-2}$ year $^{-1}$, equivalent to $66-359 \mathrm{mg} \mathrm{C} \mathrm{m}^{-2}$ day $^{-1}$, based on water column estimated rates only. Kimmerer et al. (2012) suggested phytoplankton photosynthetic rates were at the lower end of Jassby et al.'s range. Jassby et al. (2002) calculated an average water column chlorophyll $a$ concentration of $\sim 5 \mathrm{mg} \mathrm{m}^{-3}$; to obtain the equivalent median areal concentration of sediment chlorophyll $a$ at the Delta sites measured here, a $\sim 4 \mathrm{~m}$ water column would be required. Given that the Bay Delta has long been considered a system of exceptionally low phytoplankton productivity (Jassby et al. 2002; Kimmerer et al. 2012), the potentially high contribution of benthic productivity could significantly alter that perspective. Depending on depth, or the proportion of Delta sediment that has sufficient light to support benthic microalgal photosynthesis, benthic microalgae could represent an important proportion of photosynthesis in the Delta. However, further measurements of benthic chlorophyll $a$, photosynthesis, and benthic microalgal effects on nutrient flux (e.g., Sundback et al. 2000; MacIntyre et al. 2004) are necessary to better constrain the relative importance of benthic microalgae, particularly using controlled light incubations. The role of variable depth and light attenuation in such macrotidal environments require modeling efforts to best predict productivity. The lack of detailed hypsography necessarily limits the strength of these conclusions, but inclusion of microalgae in system productivity estimates may be important.

A difference in the eastern delta and the more saline bays is the presence/absence of benthic microalgae, with system hypsography and light penetration being major controls on benthic algal biomass. Regardless of salinity, the supply of labile organic matter to sediment is also a key determinant of sediment $\mathrm{N}$ fluxes. As in other shallow ecosystems, benthic microalgae exert a large influence on nutrient flux dynamics (Tyler et al. 2003). Moreover, the potential nutritional benefits of benthic microalgae to higher trophic levels (Middelburg et al. 2000) may be important to the Bay Delta ecosystem trophic dynamics.

The release of sediment DIN (the sum of $\mathrm{NH}_{4}{ }^{+}+\mathrm{NO}_{3}{ }^{-}$) represent a potentially important $\mathrm{N}$ input to the water column that can support water column primary production (Fisher et al. 1982). The average rates of DIN release in Delta and Bay environments were 1.1 and $1.7 \mathrm{mmol} \mathrm{m}^{-2}$ day $^{-1}$ in September; using Redfield stoichiometry for $\mathrm{C} / \mathrm{N}$, this could support algal productivity of 87 and $135 \mathrm{mg} \mathrm{C} \mathrm{m}^{-2}$ day $^{-1}$, respectively. Thus, in September, such remineralization provides an amount of $\mathrm{N}$ roughly equivalent to the nutritional needs of the phytoplankton community. In March, there was a
Table 5 Summary of total net $\mathrm{P}$ input for the length of Sacramento (SAC) and San Joaquin Rivers (SJR) indicated

All data are based on values from the early 2000 s, as reported by Sobota et al. (2011)

\begin{tabular}{|c|c|c|c|c|c|}
\hline & $\begin{array}{l}\text { Total area } \\
\left(\mathrm{km}^{-2}\right)\end{array}$ & $\begin{array}{l}\text { River TP yield } \\
\left(\mathrm{kg} \mathrm{P} \mathrm{km}^{-2} \text { year }^{-1}\right)\end{array}$ & $\begin{array}{l}\text { Daily TP yield } \\
\left(\mathrm{kg} \mathrm{P} \mathrm{km}^{-2} \text { day }^{-1}\right)\end{array}$ & $\begin{array}{l}\text { Total daily } \\
\text { net TP yield } \\
\left(\mathrm{kg} \mathrm{P}^{-1 a y^{-1}}\right)\end{array}$ & $\begin{array}{l}\text { Total daily } \\
\text { net } \mathrm{P} \text { yield } \\
\text { (tonnes } \mathrm{P} \text { day }^{-1} \text { ) }\end{array}$ \\
\hline SAC & 61,721 & 21 & 0.057 & 3,518 & 3.5 \\
\hline SJR & 19,030 & 14 & 0.038 & 723 & 0.7 \\
\hline
\end{tabular}


net uptake of DIN balanced by $\mathrm{N}_{2}-\mathrm{N}$ flux that results in a potential loss of $\mathrm{N}$ to the phytoplankton community.

The role of Delta sediments in the nutrient balance in this ecosystem can be compared to nutrient loading rates for the Bay Delta ecosystem, recognizing that any extrapolations at the current time are constrained because of indeterminate areas of photosynthetic sediments. We view these calculations as providing preliminary information on the relative scales of these processes. The daily average $\mathrm{N}_{2}-\mathrm{N}$ flux rate calculated over $24 \mathrm{~h}$ of light/dark conditions from this study ranged from 0.7 to $0.9 \mathrm{mmol} \mathrm{m}^{-2} \mathrm{day}^{-1}$; when extrapolated to the whole Delta area of $2.310^{8} \mathrm{~m}^{2}$ (Jassby et al. 2002), 2.2-2.9 $\mathrm{t} \mathrm{N}$ day $^{-1}$ would be removed via this process. For comparison, recognizing that such estimates at the current time are approximate, the $\sim 2.5 \mathrm{t} \mathrm{N}$ removed via denitrification is roughly one sixth of the $\sim 15 \mathrm{t} \mathrm{N}$ day ${ }^{-1}$ of the wastewater load from the Sacramento Regional Wastewater Facility on the Sacramento River (Glibert et al. 2011). Using the integrative estimates from the Lower Sacramento and San Joaquin Rivers provided by Sobota et al. (2009; Table 4), denitrification would represent one tenth of the total daily net $\mathrm{N}$ yield of these two rivers. Using the benthic microalgal requirement for $\mathrm{N}$ based on Redfield stoichiometry, a maximum uptake estimate of 2-5 t $\mathrm{N}$ day ${ }^{-1}$ within this community is calculated. Depending on the area of benthic photosynthetic uptake, this suggests that an amount up to $20 \%$ of the inputs could either be removed via denitrification or taken up by benthic microalgal photosynthesis.

The benthic microalgal requirement for $\mathrm{P}$ would be equivalent to $0.3-0.7 \mathrm{t} \mathrm{P}$ day $^{-1}$, with wastewater loading rates from the Sacramento Wastewater Treatment Facility of 1-2 $t$ $\mathrm{P}_{\text {day }}{ }^{-1}$ (Glibert et al. 2011). Similarly, using the integrative estimates of total $\mathrm{P}$ yields for these rivers provided by Sobota et al. (2011; Table 5), the removal of P due to benthic uptake would be in the range of 10-100\%. Although such budgetary estimates are approximate, they suggest a greater potential for $\mathrm{N}$ relative to $\mathrm{P}$ to be exported downstream where it may support phytoplankton production displaced spatially from the upstream sources.

In summary, rates of sediment nutrient fluxes were shown to be significant and dynamic, with regional variability from the freshwater delta to the more saline Suisun Bay. Rates of the processes measured here fell largely within the broad range of rates for such processes reported worldwide. While rates of $\mathrm{N}$ and $\mathrm{P}$ fluxes had been hypothesized to be higher in the late summer than spring, due to the contribution of increased microalgae during late summer, many of the fluxes were, in fact, higher in spring than summer. Extrapolating from both chlorophyll $a$ and $\mathrm{O}_{2}$ fluxes, the sediments may potentially have large impacts on estimates of total system productivity. While these data have provided the first such estimates of nutrient fluxes for this region of the Bay Delta, these rates are nevertheless limited in scope. They represent only two seasons and only the more shallow sites of the Bay Delta. There is much more to be understood regarding the controls on these rates, their regional and seasonal variability, and how such rates may be impacted by biotic changes, such as those of the invasive clam, Potamocorbula.

Acknowledgments This work was supported by the State and Federal Contractors Water Agency, grant 12-12. We thank David Morgan and David Bell from the R/V Questuary and Jeffrey Alexander for field and logistical assistance. Logistical support was also provided by R. Dugdale, F. Wilkerson, and A.E. Parker of the Romberg Tiburon Laboratory, and analytical support was provided by the Horn Point Analytical Services Laboratory. This is contribution number 4851 from the University of Maryland Center for Environmental Science.

Open Access This article is distributed under the terms of the Creative Commons Attribution License which permits any use, distribution, and reproduction in any medium, provided the original author(s) and the source are credited.

\section{References}

Aller, R.C. 1980. Diagenetic processes near the sediment-water interface of Long Island Sound. I. Decomposition and nutrient element geochemistry (S, N, P). Advances in Geophysics 22: 237-350.

Alpine, A.E., and J.E. Cloern. 1992. Trophic interactions and direct physical effects control phytoplankton biomass and production in an estuary. Limnology and Oceanography 37: 946-955.

An, S.M., and W.S. Gardner. 2002. Dissimilatory nitrate reduction to ammonium (DNRA) as a nitrogen link, versus denitrification as a sink in a shallow estuary (Laguna Madre/Baffin Bay, Texas). Marine Ecology-Progress Series 237: 41-50.

An, S., W.S. Gardner, and T.M. Kana. 2001. Simultaneous measurement of denitrification and nitrogen fixation using isotope pairing with membrane inlet mass spectrometry analysis. Applied and Environmental Microbiology 67: 1171-1178.

Anderson, J.M. 1982. Effect of nitrate concentration in lake water on phosphate release from the sediment. Water Research 16: 1119 1126.

Banta, G.T., A.E. Giblin, J. Tucker, and J.E. Hobbie. 1994. Comparison of two indirect methods for estimating denitrification rates for Buzzards Bay, Massachusetts. In Changes in fluxes in estuaries: implications from science to management, ed. K.R. Dyer and R.J. Orth, 203-209. Fredensborg: Olsen \& Olsen.

Berg, G.M., P.M. Glibert, N.O.G. Jorgensen, M. Balode, and I. Purina. 2001. Variability in inorganic and organic nitrogen uptake associated with riverine nutrient input in the Gulf of Riga, Baltic Sea. Estuaries 24: 176-186.

Boynton, W.R., and W.M. Kemp. 2008. Estuaries. In Nitrogen in the marine environment, eds. Capone, D.G, Bronk, DA, Mulholland, M.R., and E.J. Carpenter, 809-866. New York: Academic Press.

Caffrey, J.M. 1995. Spatial and seasonal patterns in sediment nitrogen remineralization and ammonium concentrations in San Francisco Bay, California. Estuaries 18: 219-233.

Caffrey, J.M., N. Harrington, and B.B. Ward. 2002. Biogeochemical processes in a small California estuary. 1. Benthic fluxes and pore water constituents reflect high nutrient freshwater inputs. Marine Ecology-Progress Series 233: 39-53.

Caffrey, J.M., J.T. Hollibaugh, N. Bano, and J. Haskins. 2010. Effects of upwelling on short-term variability in microbial and biogeochemical 
processes in estuarine sediments from Elkhorn Slough, California, USA. Aquatic Microbial Ecology 58: 261-271.

Caraco, N., J. Cole, and G.E. Likens. 1990. A comparison of phosphorus immobilization in sediments of freshwater and coastal marine systems. Biogeochemistry 9: 277-290.

Chambers, R.M., J.W. Fourqurean, J.T. Hollibaugh, and S.M. Vink. 1995. Importance of terrestrially-derived, particulate phosphorus to phosphorus dynamics in a west-coast estuary. Estuaries 18: 518-526.

Cook, P.L.M., E.C.V. Butler, and B.D. Eyre. 2004a. Carbon and nitrogen cycling on intertidal mudflats of a temperate Australian estuary. I. Benthic metabolism. Marine Ecology-Progress Series 280: 25-38.

Cook, P.L.M., B.D. Eyre, R. Leeming, and E.C.V. Butler. 2004b. Benthic fluxes of nitrogen in the tidal reaches of a turbid, high-nitrate subtropical river. Estuarine, Coastal and Shelf Science 59: 675-685.

Cornwell, J.C., W.M. Kemp, and T.M. Kana. 1999. Denitrification in coastal ecosystems: environmental controls and aspects of spatial and temporal scale. Aquatic Ecology 33: 41-54.

Dollar, S.J., S.V. Smith, S.M. Vink, S. Obrebski, and J.T. Hollibaugh. 1991. Annual cycle of benthic nutrient fluxes in Tomales Bay, California, and conttributions of the benthos to total ecosystem metabolism. Marine Ecology Progress Series 79: 115-125.

Dugdale, R.C., F.P. Wilkerson, V.E. Hogue, and A. Marchi. 2007. The role of ammonium and nitrate in spring bloom development in San Francisco Bay. Estuarine, Coastal and Shelf Science 73: 17-29.

Eyre, B.D., and A.J.P. Ferguson. 2002. Comparison of carbon production and decomposition, benthic nutrient fluxes and denitrification in seagrass, phytoplankton, benthic microalgae- and macroalgaedominated warm-temperate Australian lagoons. Marine EcologyProgress Series 229: 43-59.

Eyre, B.D., and A.J.P. Ferguson. 2005. Benthic metabolism and nitrogen cycling in a subtropical east Australian Estuary (Brunswick): temporal variability and controlling factors. Limnology and Oceanography 50: 81-96.

Fear, J.M., S.P. Thompson, T.E. Gallo, and H.W. Paerl. 2005. Denitrification rates measured along a salinity gradient in the eutrophic Neuse River Estuary, North Carolina, USA. Estuaries 28: 608-619.

Ferguson, A.J.P., B.D. Eyre, and J.M. Gay. 2004. Benthic nutrient fluxes in euphotic sediments along shallow sub-tropical estuaries, northern New South Wales, Australia. Aquatic Microbial Ecology 37: 219-235.

Fisher, T.R., P.R. Carlson, and R.T. Barber. 1982. Sediment nutrient regeneration in three North Carolina estuaries. Estuarine, Coastal and Shelf Science 14: 101-116.

Froelich, P.N. 1988. Kinetic control of dissolved phosphate in natural rivers and estuaries: a primer on the phosphate buffer mechanism. Limnology and Oceanography 33: 649-668.

Gao, Y., J.C. Cornwell, D.K. Stoecker, and M.S. Owens. 2012. Effects of cyanobacterial-driven $\mathrm{pH}$ increases on sediment nutrient fluxes and coupled nitrification-denitrification in a shallow fresh water estuary. Biogeosciences 9: 2697-2710.

Gardner, W.S., S.P. Seitzinger, and J.M. Malczyk. 1991. The effect of sea salts on the forms of nitrogen released for estuarine and freshwater sediments: does ion pairing affect ammonium flux? Estuaries 14: $157-166$.

Gardner, W.S., M.J. McCarthy, D. Sobolev, A. Soonmo, K.S. Sell, and D. Brock. 2006. Nitrogen fixation and dissimilatory nitrate reduction to ammonium (DNRA) support nitrogen dynamics in Texas estuaries. Limnology and Oceanography 51: 558-568.

Gardolinski, P., P.J. Worsfold, and I.D. McKelvie. 2004. Seawater induced release and transformation of organic and inorganic phosphorus from river sediments. Water Research 38: 688-692.

Glibert, P.M. 2010. Long-term changes in nutrient loading and stoichiometry and their relationships with changes in the food web and dominant pelagic fish species in the San Francisco Estuary, California. Reviews in Fisheries Science 18: 211-232.

Glibert, P.M., D. Fullerton, J.M. Burkholder, J.C. Cornwell, and T.M. Kana. 2011. Ecological stoichiometry, biogeochemical cycling, invasive species, and aquatic food webs: San Francisco Estuary and comparative systems. Reviews in Fisheries Science 19: 358417.

Glibert, P.M., J.M. Burkholder, and T.M. Kana. 2012. Recent insights about relationships between nutrient availability, forms, and stoichiometry, and the distribution, ecophysiology, and food web effects of pelagic and benthic Prorocentrum species. Harmful Algae 14: 231-259.

Greene, V.E., L.J. Sullivan, J.K. Thompson, and W.J. Kimmerer. 2011. Grazing impact of the invasive clam Corbula amurensis on the microplankton assemblage of the northern San Francisco Estuary. Marine Ecology-Progress Series 431: 183-193.

Guarini, J.M., J.E. Cloern, J. Edmunds, and P. Gros. 2002. Microphytobenthic potential productivity estimated in three tidal embayments of the San Francisco Bay: a comparative study. Estuaries 25: 409-417.

Hartzell, J.L., T.E. Jordan, and J.C. Cornwell. 2010. Phosphorus burial in sediments along the salinity gradient of the Patuxent River, a subestuary of the Chesapeake Bay (USA). Estuaries and Coasts 33: 92-106.

Hochard, S., C. Pinazo, C. Grenz, J.L.B. Evans, and O. Pringault. 2010. Impact of microphytobenthos on the sediment biogeochemical cycles: a modeling approach. Ecological Modelling 221: 1687-1701.

Jassby, A. 2008. Phytoplankton in the upper San Francisco Estuary: recent biomass trends, their causes and their trophic significance. San Francisco Estuary and Watershed Science. http://escholarship. org/uc/item/71h077r1. Accessed 2008

Jassby, A.D., W.J. Kimmerer, S.G. Monismith, C. Armor, J.E. Cloern, T.M. Powell, J.R. Schubel, and T.J. Vendlinski. 1995. Isohaline position as a habitat indicator for estuarine populations. Ecological Applications 5: 272-289.

Jassby, A.D., J.E. Cloern, and B.E. Cole. 2002. Annual primary production: patterns and mechanisms of change in a nutrient-rich tidal ecosystem. Limnology and Oceanography 47: 698-712.

Jordan, T.E., J.C. Cornwell, W.R. Boynton, and J.T. Anderson. 2008. Changes in phosphorus biogeochemistry along an estuarine salinity gradient: the iron conveyer belt. Limnology and Oceanography 53: $172-184$.

Joye, S. B., and I. C. Anderson. 2008. Nitrogen cycling in coastal sediments, p. 868-915. In Nitrogen in the marine environment, 2nd edition, eds. Capone, D.G., Bronk, D.A., Mulholland, M.R., and E. J. Carpenter. New York: Academic Press.

Kana, T.M., and D.L. Weiss. 2004. Comment on "Comparison of isotope pairing and N-2: Ar methods for measuring sediment denitrification". By Eyre, B.D., Rysgaard, S., Daisgaard, T., and P. Bondo Christensen. 2002. Estuaries 25: 1077-1087. Estuaries 27:173176.

Kana, T.M., C. Darkangelo, M.D. Hunt, J.B. Oldham, G.E. Bennett, and J.C. Cornwell. 1994. Membrane inlet mass spectrometer for rapid high-precision determination of $\mathrm{N}_{2}, \mathrm{O}_{2}$, and $\mathrm{Ar}$ in environmental water samples. Analytical Chemistry 66: 4166-4170.

Kana, T.M., M.B. Sullivan, J.C. Cornwell, and K. Groszkowski. 1998. Denitrification in estuarine sediments determined by membrane inlet mass spectrometry. Limnology and Oceanography 42: 334-339.

Kemp, W.M., W.R. Boynton, J.E. Adolf, D.F. Boesch, W.C. Boicourt, G. Brush, J.C. Cornwell, T.R. Fisher, P.M. Glibert, J.D. Hagy, L.W. Harding, E.D. Houde, D.G. Kimmel, W.D. Miller, R.I.E. Newell, M.R. Roman, E.M. Smith, and J.C. Stevenson. 2005. Eutrophication of Chesapeake Bay: historical trends and ecological interactions. Marine Ecology-Progress Series 303: 1-29.

Kimmerer, W.J., A.E. Parker, U.E. Lidstrom, and E.J. Carpenter. 2012. Short-term and interannual variability in primary production in the low-salinity zone of the San Francisco Estuary. Estuaries and Coasts 35: 913-929.

Kuwabara, J.S., Topping, B.R., Parchaso, F., Engelstad, A.C., and V. E. Greene. 2009. Benthic flux of nutrients and trace metals in the northern component of San Francisco Bay, California: U.S. 
Geological Survey Open-File Report 2009-1286, p. 14. U.S. Geological Survey.

Laursen, A.E., and S.P. Seitzinger. 2002. The role of denitrification in nitrogen removal and carbon mineralization in Mid-Atlantic Bight sediments. Continental Shelf Research 22: 1397-1416.

Lehtoranta, J., P. Ekholm, and H. Pitkanen. 2009. Coastal eutrophication thresholds: a matter of sediment microbial processes. Ambio 38: 303-308.

MacIntyre, H.L., R.J. Geider, and D.C. Miller. 1996. Microphytobenthos: the ecological role of the "secret garden" of unvegetated, shallowwater marine habitats 0.1 . Distribution, abundance and primary production. Estuaries 19: 186-201.

MacIntyre, H.L., M.W. Lomas, J. Cornwell, D.J. Suggett, C.J. Gobler, E.W. Koch, and T.M. Kana. 2004. Mediation of benthic-pelagic coupling by microphytobenthos: an energy- and material-based model for initiation of blooms of Aureococcus anophagefferens. Harmful Algae 3: 403-437.

Middelburg, J.J., C. Barranguet, H.T.S. Boschker, P.M.J. Herman, T. Moens, and C.H.R. Heip. 2000. The fate of intertidal microphytobenthos carbon: an in situ ${ }^{13} \mathrm{C}$ labeling study. Limnology and Oceanography 45: 1224-1234.

Mortimer, C.H. 1971. Chemical exchanges between sediments and water in the Great Lakes - speculations on probable regulatory mechanisms. Limnology and Oceanography 16: 387-404.

Newell, R.I.E., J.C. Cornwell, and M.S. Owens. 2002. Influence of simulated bivalve biodeposition and microphytobenthos on sediment nitrogen dynamics: a laboratory study. Limnology and Oceanography 47: 1367-1379.

Nilsen, E.B., and M.L. Delaney. 2005. Factors influencing the biogeochemistry of sedimentary carbon and phosphorus in the Sacramento-San Joaquin Delta. Estuaries 28: 653-663.

Nixon, S.W., J.W. Ammerman, L.P. Atkinson, V.M. Berounsky, G. Billen, W.C. Boicourt, W.R. Boynton, T.M. Church, D.M. DiToro, R. Elmgren, J.H. Garber, A.E. Giblin, R.A. Jahnke, N.J.P. Owens, M.E.Q. Pilson, and S.P. Seitzinger. 1996. The fate ofnitrogen and phosphorus at the land-sea margin of the North Atlantic Ocean. Biogeochemistry 35: 141-180.

Owens, M.S. 2009. Nitrogen cycling and controls on denitrification in mesoahaline sediment of Chesapeake Bay. College Park: MEES Program, University of Maryland.

Parker, A.E., V.E. Hogue, F.P. Wilkerson, and R.C. Dugdale. 2012. The effect of inorganic nitrogen speciation on primary production in the San Francisco Estuary. Estuarine, Coastal and Shelf Science 104: 91-101.

Pelegri, S.P., L.P. Nielsen, and T.H. Blackburn. 1994. Denitrification in estuarine sedimentstimulated by the irrigation activity of the amphipod Corophium volutator. Marine Ecology Progress Series 105: 285-290.

Porubsky, W.P., N.B. Weston, and S.B. Joye. 2009. Benthic metabolism and the fate of dissolved inorganic nitrogen in intertidal sediments. Estuarine, Coastal and Shelf Science 83: 392-402.

Risgaard-Petersen, N., R.L. Meyer, M. Schmid, M.S.M. Jetten, A. Enrich-Prast, S. Rysgaard, and N.P. Revsbech. 2004. Anaerobic ammonium oxidation in an estuarine sediment. Aquatic Microbial Ecology 36: 293-304.

Rysgaard, S., N. Risgaard-Petersen, N.P. Sloth, K. Jensen, and L.P. Nielsen. 1994. Oxygen regulation of nitrification and denitrification in sediments. Limnology and Oceanography 39: 1643-1652.

Seitzinger, S.P. 1991. The effect of $\mathrm{pH}$ on the release of phosphorus from Potomac estuary sediments: implications for blue-green algal blooms. Estuarine, Coastal and Shelf Science 33: 409-418.

Seitzinger, S.P., W.S. Gardner, and A.L. Spratt. 1991. The effect of salinity on ammonium sorption in aquatic sediments: implications for benthic nutrient recycling. Estuaries 14: 167-174.

Sobota, D.J., J.A. Harrison, and R.A. Dahlgren. 2009. Influences of climate, hydrology, and land use on input and export of nitrogen in California watersheds. Biogeochemistry. doi:10.1007/s10533009-9307-y.

Sobota, D.J., J.A. Harrison, and R.A. Dahlgren. 2011. Linking dissolved and particulate phosphorus export in rivers draining California's Central Valley with anthropgenic sources at the regional scale. Journal of Environmental Quality 40: 1290-1302.

Sundback, K., A. Miles, and E. Goransson. 2000. Nitrogen fluxes, denitrification and the role of microphytobenthos in microtidal shallow-water sediments: an annual study. Marine EcologyProgress Series 200: 59-76.

Tyler, A.C., K.J. McGlathery, and I.C. Anderson. 2003. Benthic algae control sediment-water column fluxes of organic and inorganic nitrogen compounds in a temperate lagoon. Limnology and Oceanography 48: 2125-2137.

Van Heukelem, L., A.J. Lewitus, T.M. Kana, and N.E. Craft. 1994. Improved separations of phytoplankton pigmets using temperature-controlled high performance liquid chromatorgrapy. Marine Ecology Progress Series 114: 303-313.

Van Nieuwenhuyse, E. 2007. Response of summer chlorophyll concentration to reduced total phosphorus concentration in the Rhine River (Netherlands) and the Sacramento-San Joaquin Delta (California, USA). Canadian Journal of Fisheries and Aquatic Sciences 64: $1529-1542$.

Wanger, O.W. 2007a. Findings of fact and conclusions of law re interim remedies re: delta smelt ESA remand and reconsultation. Case 1:05cv-01207-OWW-GSA, Document 01561. United States District Court, Eastern District of California, Fresno, California.

Wanger, O.W. 2007b. Interim remedial order following summary judgment and evidentiary hearing. Case 1:05-cv-01207-OWW-GSA, Document 01560. United States District Court, Eastern District of California, Fresno, California.

Webb, A.P., and B.D. Eyre. 2004. Effect of natural populations of burrowing thalassinidean shrimp on sediment irrigation, benthic metabolism, nutrient fluxes and denitrification. Marine EcologyProgress Series 268: 205-220.

Williams, J.D.H., J.K. Syers, S.S. Shukla, R.F. Harris, and D.E. Armstrong. 1971. Levels of inorganic and total phosphorus in lake sediments as related to other sediment paramenters. Environmental Science and Technology 5: 1113-1120. 